\title{
Vaginal Mullerian Papilloma
}

National Cancer Institute

\section{Source}

National Cancer Institute. Vaginal Mullerian Papilloma. NCI Thesaurus. Code C40255.

A benign papilloma that arises from the vagina in infants and young women. 